\title{
FIFTEEN RULES OF CHRISTOPHER ALEXANDER AND THE METHODS OF GENERATIVE DESIGN AS THE PRACTICAL APPLICATION OF THE „THE NATURE OF ORDER“ IN ARCHITECTURE
}

\section{A B S T R A C T}

This paper establishes the correlation between the "nature of order“ of Christopher Alexander and the methods of generative design as well as their connection with nature. The research is focused on the practical application of Christopher Alexander's theory on assuming the principles from the nature, with an objective of reconciliation of the built environment with nature and creation of the more agreeable living environment than the present one, by means of generative, parametric design in architecture and urbanism.

Christopher Alexander sees order in nature, whereas the human kind creates a completely new type of "order" constructing buildings and cities, even though not fully aware of the meaning of this notion. In order to establish the balance between these two orders, namely the unity between these two complex systems - the natural and artificial ones, according to Christopher Alexander, it is necessary to make transition of the principles from a well functioning system, the nature, into the artificial system. This paper explores the connection of the "nature of order" that is to say the "fifteen properties" of Christopher Alexander with the methods of generative design, in parallel search for correlation in the nature. The rules are associated with the methods of self-organisation and evolution methods being the primary methods of generative design. 


\section{INTRODUCTION}

This paper establishes the correlation between fifteen rules of Christopher Alexander, that is to say fifteen properties as he also calls them in the book "The Nature of Order - The Phenomenon of Life" ${ }^{\text {"1 }}$ and the methods of research in generative, parametric design by connecting the same with the nature. This correlation also indicates to the development of the theory of nature of order by Christopher Alexander and its practical application, and thus this paper studies the topic within this domain as well.

The properties of Christopher Alexander are not all equally represented in the methods of generative design. Some rules can be explained to a greater extent mathematically and used when generating, like the levels of scale, boundaries, local symmetries, whereas the others are more associated with the experience and feelings of the people when encountering them, like the oneness and inner calm. This paper considers the representation of the properties in the methods and the reasons for the absence of certain properties.

As the most essential characteristic of nature as a complex system for generative design the following have been emphasized: organized complexity - compression, synthesis of multitude of information, which results in life either biological or artificial, namely within this theme architectural and urban: multiplication, self-reproduction of buildings with improvements through evolution: adaptations by means of which an organism changes in relation to the environment in order to make better use of it: contrary to adaptation, the intervention by means of which an organism changes the environment in respect to its needs, linking, namely continuous flow of information, communication of a part with a whole and vice versa, in order for the organism to feel the changes of the environment and in that way become situated. ${ }^{2}$ These characteristics make integral parts of the systems which form the methods of research of generative systems - the systems of self-organisation and evolution systems.

The rules of Christopher Alexander and the methods of generative design, being closely connected by the relationship of the factors and the whole, as well as the initial units and developed element, present the theme of the paper which explains the nature of their relation and translating the theory into practical application. Also, it is possible to connect both concepts and promote them through mathematical concept, which has initially been studied in this paper and presented as the topic for future research. 


\section{NATURE OF ORDER OF CHRISTOPHER ALEXANDER}

The book "The Nature of Order -The Phenomenon of Life“" 3 by Christopher Alexander is about the concept of the world and universe which is valid only if the people are similar to a great extent, which he believes in. Feelings are diverse and not everyone experiences the same situation in the same manner, through the same feelings, however, in the book "A Pattern Language" Christopher, as stated there, orientates himself towards ninety percent of feelings which are the same in people, whereas the remaining ten percent which differ in people when encountering the same situations remain neglected. ${ }^{5}$ When speaking about the nature of order, Christopher also considers the ninety percent of feelings shared by all people ${ }^{6}$, on which his contemplations written down in this book have been based.

Defining the order, phenomenon of 1 ife, a whole and theory of centers according to Christopher Alexander

In order to be able to understand the nature of order of Christopher Alexander, and thus also the properties laid down by him, it is first necessary to become familiar with the understanding of certain notions of Christopher Alexander. The notions explaining the nature of order, order, phenomenon of life, a whole and centers are written about by Christopher in his book ,The Nature of Order - The Phenomenon of Life". 7

\section{Order}

When defining the notion of order Christopher writes that people continuously experience the order. Grass, sky, leaves on the trees, windows on the houses along the street - each one of these elements present an order. That order is the one that makes a man sigh. That is the arrangement of clouds, flowers, leaves, faces - the geometrical correlation together with its meanings which man attribute to them in his mind. ${ }^{8}$ In these words Christopher already points out that the order is created by geometry, namely geometry rules which he has also incorporated within the properties he writes about in his book. However, the order that Christopher Alexander writes about does not originate from the simple mathematical shapes and their simple correlations, but through the shapes and connections that are complex and impossible to be described in the classical mathematical language. ${ }^{9}$

Christopher also attempts to explain the importance of order, both generally and in architecture, whereby he states that with construction the physical order that dominates the world is created - millions of buildings, houses, roads, cities 
covering millions of square kilometers of the globe space - and people, even though responsible for that same order are not even certain of the meaning of the notion. With the great scope of construction, namely expansion of such order, its significance within this domain is emphasized and it is considered not less significant than the order discovered in physics, chemistry or biology. These disciplines and human progress in understanding the same have changed the view of the world, and therefore the same may happen providing the order in construction and expansion of the cities is comprehended and understood differently. ${ }^{10}$

\section{Phenomenon of Life}

Alexander describes the need for a broader definition of life whereby different questions would be answered to, such as - Is virus alive? Is fertilized egg alive? Is the forest as a whole alive, since its integral parts are? Wider concept of life as described in this book proposes that each item, regardless of what it is, be it an organism or not, possesses a certain degree of livingness. ${ }^{11}$ Some items seem more alive than the others. Observing inorganic physical systems one recognizes the ones that have greater degree of life, those that have none of it and the ones in-between. Thus the surface of the Moon, the Jupiter and the Sun which in this order give the impression of progressively "more vital", even though according to the conventional definition of life ${ }^{12}$ they are not. ${ }^{13}$

\section{A Whole and Theory of Centers}

Christopher Alexander explains that the living structure is generated from the centers as a whole. Primarily it is necessary to explain the center and a whole in order to be able to understand how life originates from them.

Alexander proposes a view of the physical reality which is dominated by the existence of a certain structure, a whole. In each given space region, some subregion possesses greater intensity of centers than other sub-regions. Clusters of the centers together with their intensity form one structure - a whole. ${ }^{14}$

Centers are understood by Alexander as physical set, a distinctive physical system, occupying certain space volume and having particularly specified correlation. ${ }^{15}$ Since Christopher Alexander is first of all a mathematician, such definition has most likely originated from his mathematical thinking, which in the nature cannot precisely determine the centers, the regions belonging to it and their boundaries. In Christopher's book an example of the lake is mentioned, the questions are raised as to what makes the lake - water, its flora and fauna, and what is its boundary - the stones around it. There is not a way to 
determine precisely the lake boundary ${ }^{16}$ and for that reason Christopher defines centers in this way, as the field of organized forces in the object or its part. Each center consists of other centers, which altogether make a whole. ${ }^{17}$

Christopher Alexander explains that a living structure originates from the centers in a whole and their correlations, namely due to mutual support, and that is what challenges the life of a whole. ${ }^{18}$ Observed on the example of a tree, the three has its sub-regions, a root, a trunk, the branches. Observed on the example of a branch, they have smaller branches (twigs), leaves, pods. Also, the centers within artificial systems, such as architectural ones, produce livingness in respect to their correlations. The life of a center depends on the arrangement of the centers and their correlations and the relations with the broader system appearing in the surrounding environment since life emerges from a whole. ${ }^{19}$

\section{Fifteen Rules of Christopher Alexander}

Christopher Alexander establishes fifteen rules which lead to corresponding arrangement of the centers. The rules are the following: the levels of scale, strong centers, boundaries, alternating repetitions, positive space, good shape, local symmetries, deep interlock and ambiguity, contrast, gradients, roughness, echoes, the void, simplicity and inner calm and not-separateness. These properties control the manner in which living centers could be created with the help of other centers. ${ }^{20}$

The levels of scale appear correctly and harmoniously only when one center makes life possible for the other one. It is important that jumps from one scale to another are not overly big. ${ }^{21}$ (Figure 1) Such harmonization of the centers of scaled elements makes life of the entire system possible as well as of its parts. The strong centers are not understood as one large center, but same as with the levels of scale, as the presence of the centers of various intensities. Each strong center consists of the multitude of strong centers and it is important that the proportions of intensities be harmonized. ${ }^{22}$ Observing the structures which give an impression of livingness one notices a strong center, however, also the different levels of multitude of strong centers. (Figure 2) Strong centers are tightly connected with the levels of scale, they also determine them to same extent, but are also inter-dependent. The boundaries surround, separate, bring together by means of numerous geometry ways and it is important that the boundaries correspond to that which they surround - it is necessary that they correspond by their proportion to the center they surround. ${ }^{23}$ If the boundary is 

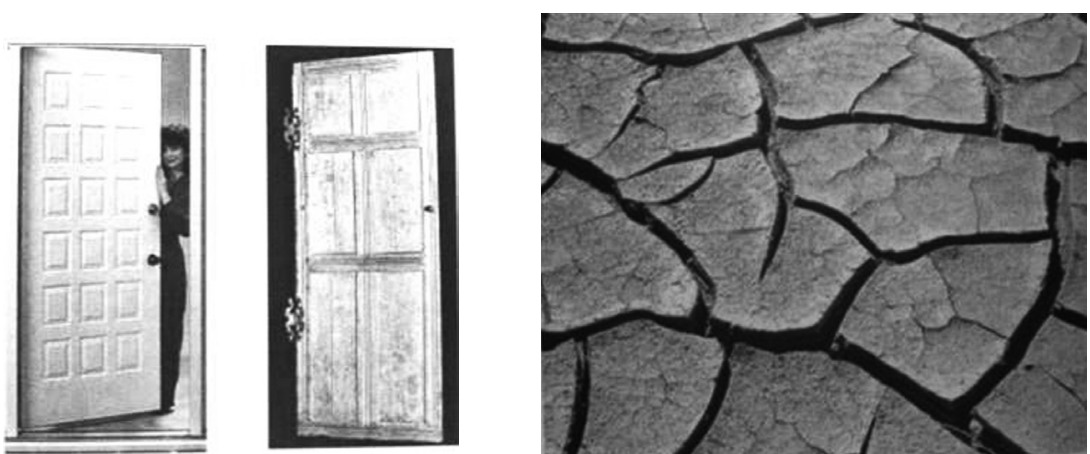

Figure 1: Left: Low degree of harmony of the levels of scale. Center: High degree of the levels of scale. Right: Example of the levels of scale in nature, crevices in the dried land
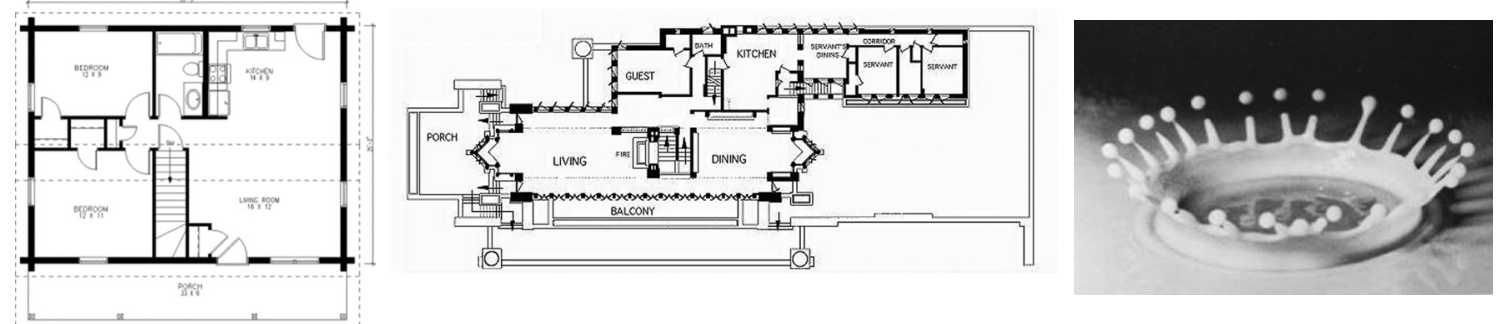

Figure 2: Left: Floor plan of an unknown building, minor harmonization of centers. Center: Frank Lloyd Wright, floor plan of the first level of the Robie residence, greater harmonization of centers. Ri ght: Example of strong centers in nature, a droplet of milk
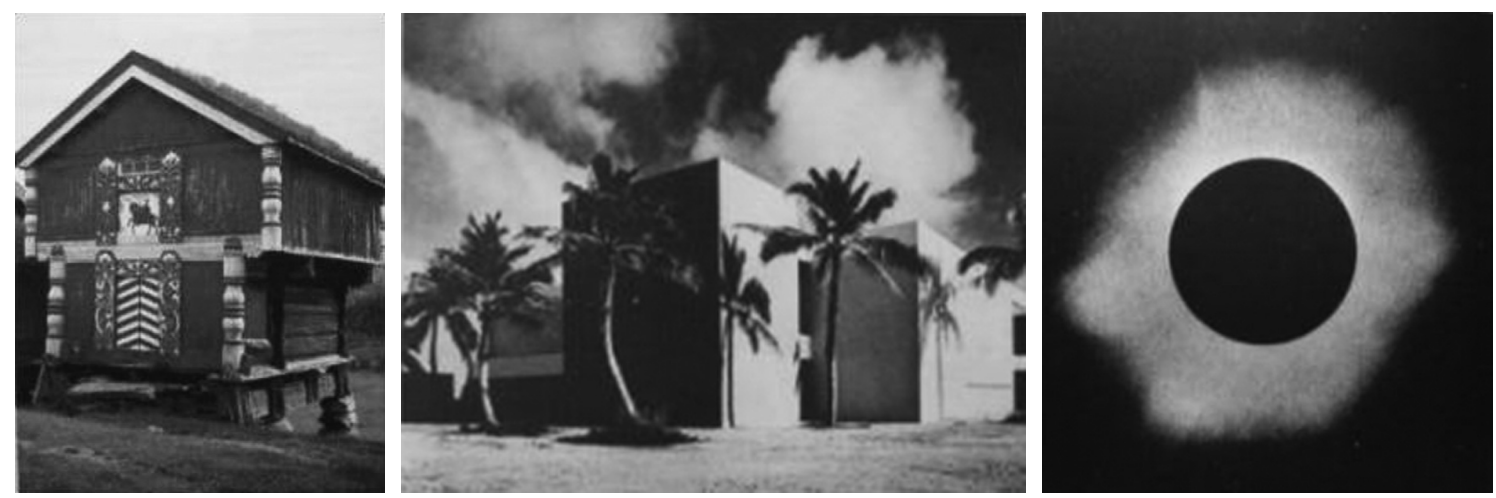

Figure 3: Left: Traditional Norwegian storage house, multitude of boundaries. Center: Building dating middle of the twentieth century, absence of boundaries. Right: Example of clear boundary in nature, crown of the Sun
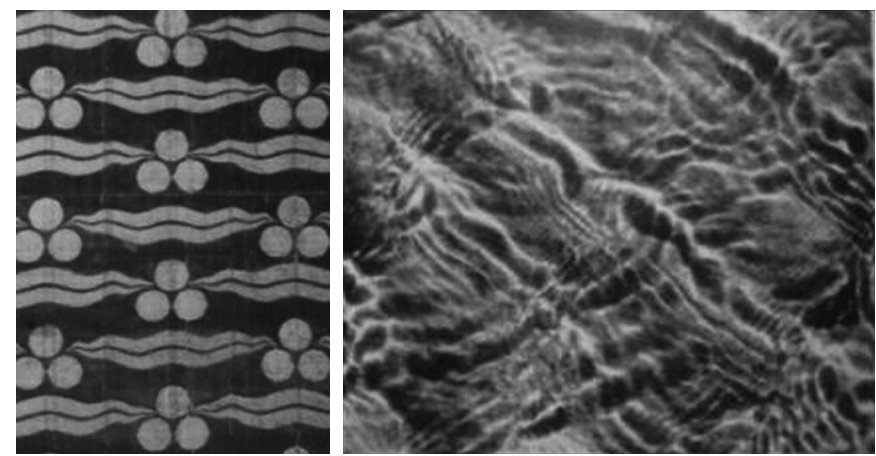

Figure 4: Left: Turkish velvet, alternating repetitions create livingness in space. Right: Example of alternating repetitions in nature, undulation of water

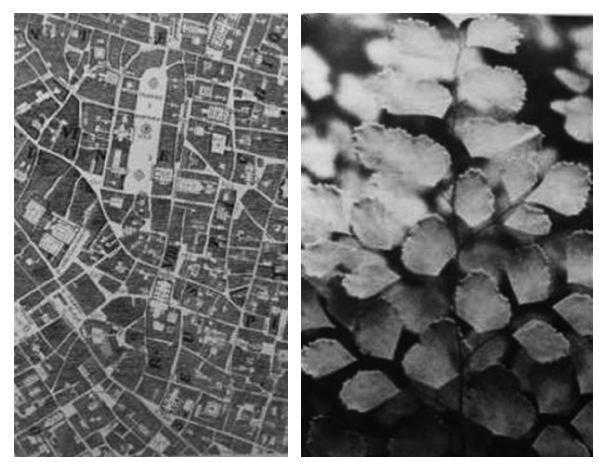

Figure 5: Left: Positive space in the Rome plan by Giambattista Nolli. Right: Example of positive space in nature, leaves 

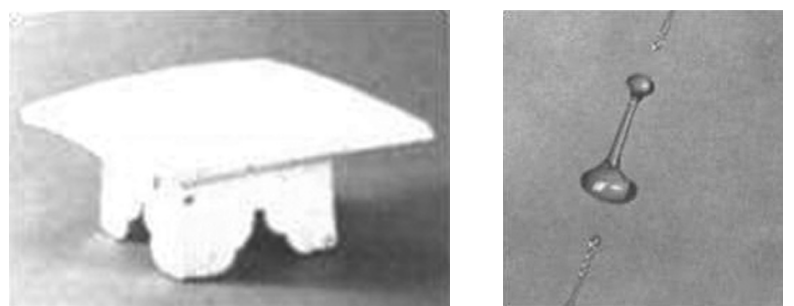

Figure 6: Left: Footstool, good shape. Right: Example of good shape in nature, drop of water
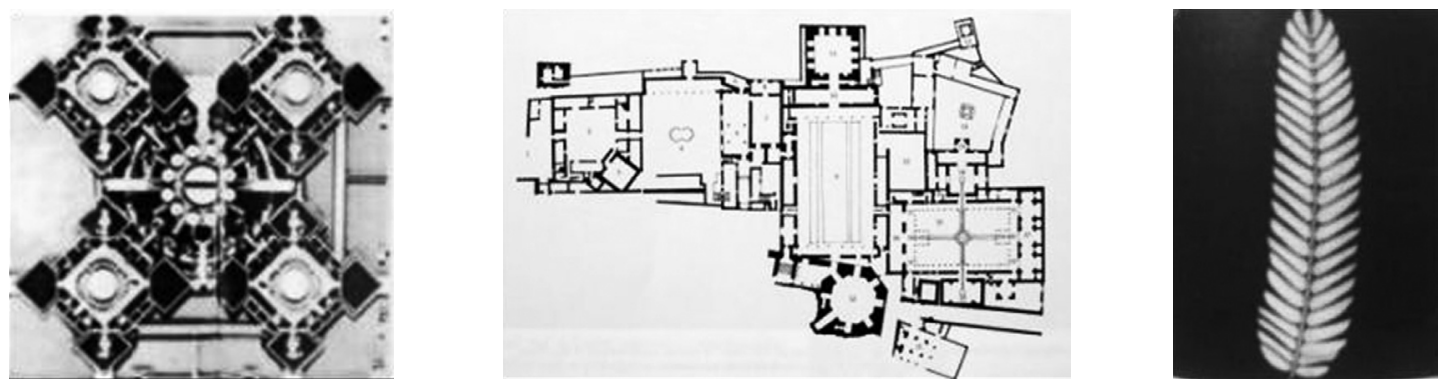

Figure 7: Left: Renaissance Center, brutal symmetry without adaptation of a whole to the parts and vice versa. Center: Alhambra, Moorish fortress in Grenada, good symmetrical order. Ri ght: Example of local symmetry in nature, fern

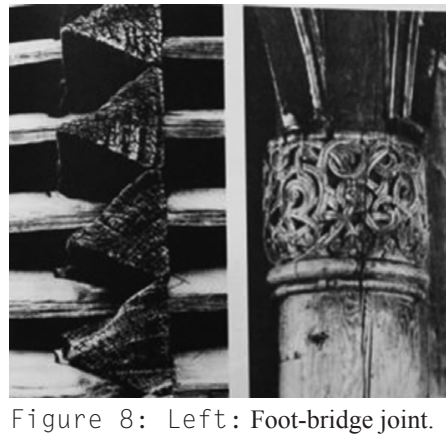

Center: Wooden capital and beam joint.
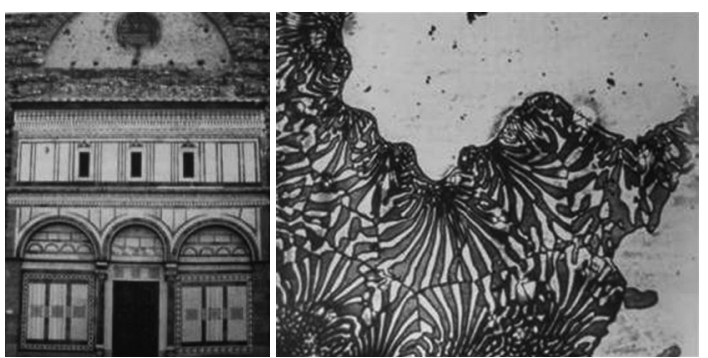

Figure 9: Left: Contrast on façade of Tuscany church. Right: Example of contrast in nature, beryllium and iron

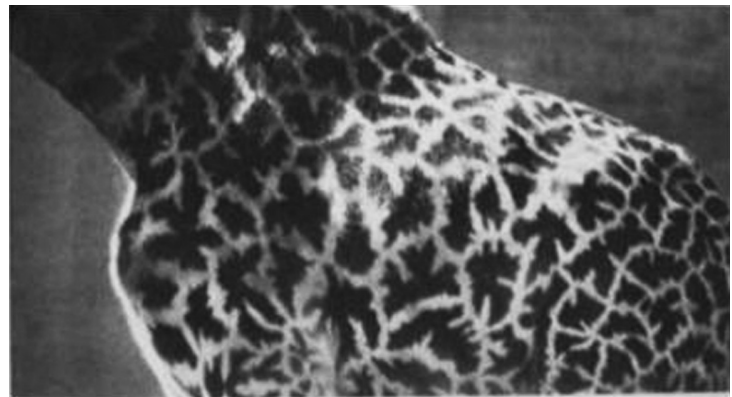

Right: Example of deep interlock in nature, the pattern of giraffe's fur
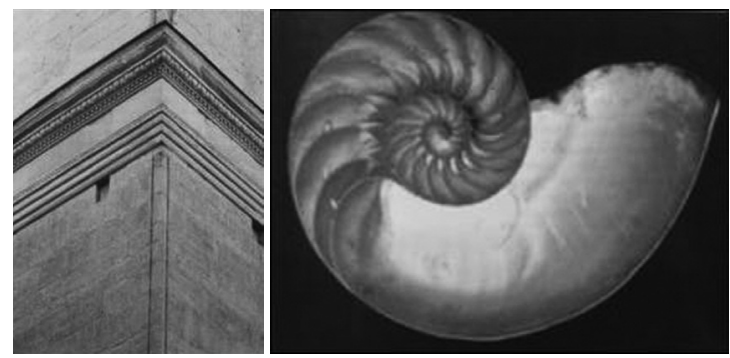

Figure 10: Left: Gradients, cornice. Right: example of gradients in nature, gradient formed by snail shell growth 

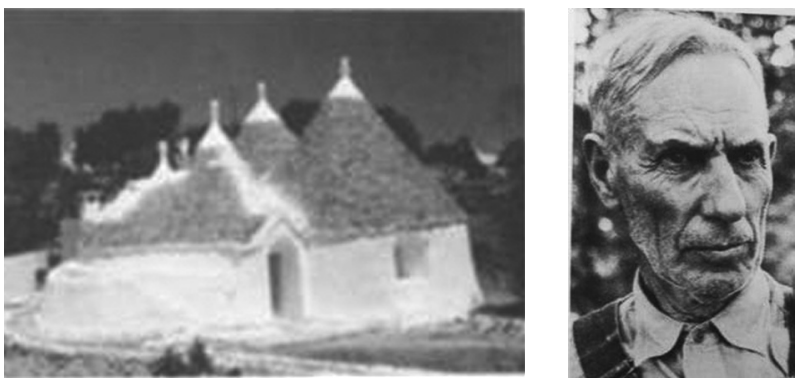

Figure 11: Left: Building in South Italy, echoes. Right: Example of echoes in nature,
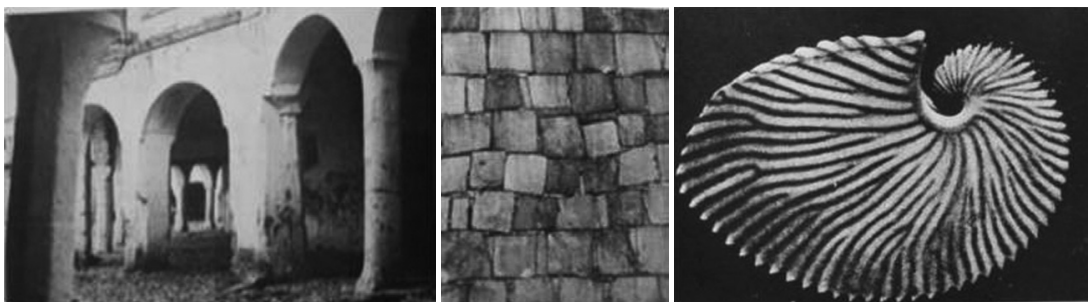

Figure 12: Left: columns that clearly, roughly accentuate the space. Center: Wall carefully filled with stone. Right: Example of roughness in nature, shell
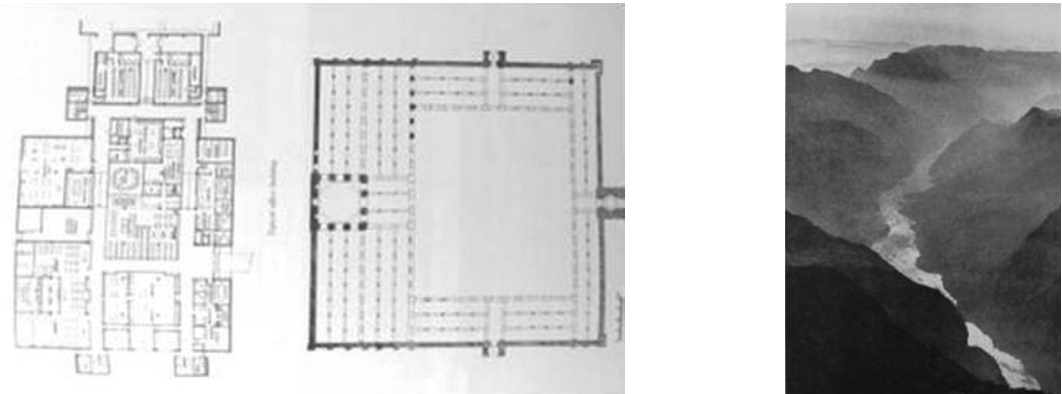

Figure 13: Left: non-expressed void in typical business building. Center: expressed void, the mosque in Cairo. Right: Example of the void in nature, gorge
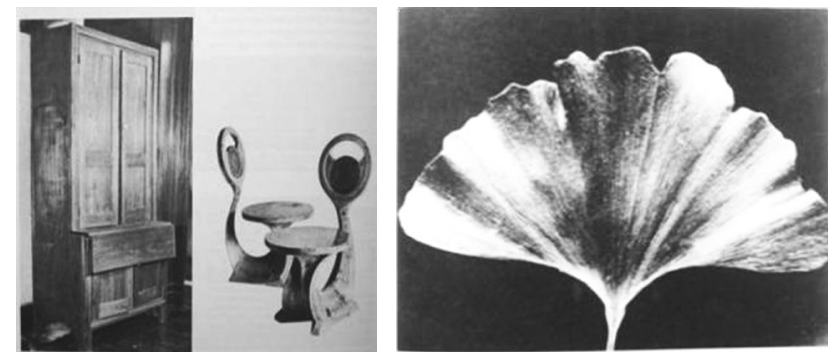

Figure 14: Left: cabinet, expressed calm. Center: Italian chairs, absence of calm. Right: Example of simplicity and inner calm in nature, the leaf of gingko
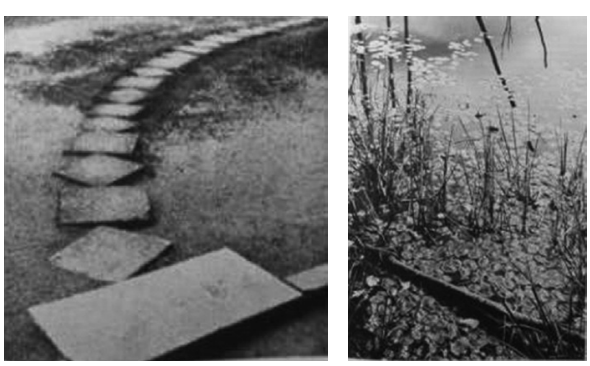

Figure 15: Left: Mutually connected path. Right: Example of not-separateness in nature, the boundary of lake 
too weak, it cannot gather that which it surrounds nor form a center. (Figure 3) Alternating repetitions are understood as repetitions by means of which the centers increase the intensity of other centers through repetitions. ${ }^{24}$ Rhythm originating by repetition creates an effect of the field which is not just a simple repetition but a field formed in relation to external effects and results in a pattern with slight deformations. (Figure 4) Positive space comprises the space which has „matured“, namely "swollen“ so that it does not endanger itself, and neither the neighboring space - like the corn grains which swell and grow until encountering other grains ${ }^{25}$ (Figure 5) A good shape results from the centers and the levels of scale. ${ }^{26}$ The structures consist of the centers which on the contrary consist of the centers of lower order but equally important and proportionally strong. (Figure 6) Local symmetry need not be literal and simple, since it provokes brutality, but it should be a symmetry in broader sense, ${ }^{27}$ the one that comprises rotations, movements, scale - self-similarity. ${ }^{28}$ A great number of minimal symmetries gives rise to self-similarity and compatibility of centers, levels of scale and thus to livingness as well (Figure 7) Deep interlock and ambiguity define the boundaries and the firm connections similar as the contrast. ${ }^{29}$ Two neighboring environments ,get hooked“ one to another whereby the effect of difficult separation and unison is achieved. (Figures 8 and 9) Gradients appear when an object is in harmony with itself - gradients change since they organize themselves in relation to themselves but also in relation to the surrounding. ${ }^{30}$ The differences appear in size, spaces, intensity, character, etc. (Figure 10) Echo is the property which relates to the repetition of the same element with small changes. Christopher explains this property as significant how people feel certain level of pleasure when encountering the known. ${ }^{31}$ (Figure 11) Roughness, namely uneven surfaces relate to the dose of irregularity which exists in each structure that is ordered. ${ }^{32}$ It appears since each structure emerges in relation to different external conditions. (Figure 12) The void is the property by means of which Christopher explains a simple, quiet, vacant, large and calm space which is required within the frames of each center in order to enable it come to life and to a whole. ${ }^{33}$ (Figure 13) Simplicity and inner calm comprise purification from each surplus center which does not aid other centers. It does not relate to purification of ornaments but to moderation and compatibility of their correlations with a whole. ${ }^{34}$ (Figure 14) Not-separateness comprises careful organization of boundaries. ${ }^{35}$ Each center makes a contribution to the property of not-separateness as far as connection with the next whole. The property of not-separateness relates to the simultaneous separateness, but not in the sense of "detachment" from other parts, but in the sense of separateness from communication. (Figure 15) 


\section{Mathematical calculation of the degree of livingness}

In his book Christopher Alexander explains also the mathematical model of Nikos Salingaros by means of which it is possible to measure the livingness of an object. Such concept additionally inspires to elaboration of connection of generative methods of design and the fifteen rule (properties), that is to say livingness, since both concepts are of mathematical origin.

Salingaros' mathematical concept is based on only two components, which makes it insufficiently precise. He uses the variables $\mathrm{H}$ and $\mathrm{T}-\mathrm{H}$ for that which he calls harmony, whereby the number of local symmetries is estimated by ascribing the values of five different types of symmetries. The total density of local symmetries is observed whereby counting and observation of the arrangement of symmetries is avoided. The variable $T$ which Salingaros calls temperature, verifies the levels of scale, contrast, boundaries and maybe even the strong centers. Temperature is also observed thought the density of appearance of this property. ${ }^{36}$

Salingaros has made the analysis of various objects through these two parameters observing them as the sum of five different parameters. Each of these parameters was assessed 0,1 or 2 depending on whether it was missing, it was partially present or intensively present. The analysis was made on the basis of observation. The results of the research were sorted in hierarchical order according to the impression of an object livingness. ${ }^{37}$

Such analysis indicates to the possibility of development of such methods and integration of the same within the present contemporary methods of design in order to promote the results. Since generative design makes use of the majority of these properties it is possible to link them directly and use this concept of calculation of livingness not only as an evolution process but also integrate it within the methods of design as well.

\section{GENERATIVE ARCHITECTURE}

Generative design as extracted from nature

Generative design ensued from the tight correlation with the nature that is to say from analogy with living structures. That which has additionally enabled and encouraged the development of such method of design are computers which are progressively becoming an indispensible part of everyday life. The result 
of that being that the role of an architect also changes. Generative systems offer methodology and philosophy which sees the world, namely everything in it, as dynamic processes with their intermediate outcomes. According to Thomas Kuhn with these systems the paradigm on design process changes and the output product is the process - a dynamic artifact, and not a static finished product. ${ }^{38}$ For an architect such system comprises reexamining of the static objects and the manners in which they are controlled. Conceptualization is shifted from the priority of an object to the constituents which interact, systems, processes, which in turn generate new artifacts, with particular properties. ${ }^{39}$

Generative design comprises software processing of input data, parameters, from the environment whereby the final product is generated, namely the organized complexity of incorporated information, as a product of temporarily halted process. As a result, such artifact containing the information from the environment, use the most essential characteristics of nature as a complex system - it has adapted and connected - smaller parts, itself, with a whole, namely environment, and its parts with a whole, and in that way became situated and adapted itself; it possesses the possibility of multiplication like a developed system which it is possible to apply with other input data; to certain extent it has the possibility of intervention, change of the environment.

The development of such design is in progress and it implies many questions. One of the issues emerges following the construction of the building. The building causes changes in the surrounding environment which most often is not possible to foresee, it emits the information in the space, but cannot adapt itself to the return information emitted by the surrounding environment ${ }^{40}$ It is necessary to develop the concepts which produce such solutions, skeletons which allow for continuous adaptation and exchange of information.

Methods of generative design

As already emphasized, the methods of generative design result from the idea of the analogy of architecture and nature as complex systems. The developed methods of generative design which are most often used in architecture are self-organization, namely self-arrangement and systems of evolution.

The systems of self-arrangement consist of a great number of relatively simple autonomous components which according to given rules combine themselves in order to construct an artifact of large proportions or interact in order to resolve the issues of a collective. ${ }^{41}$ In practice, when designing, it is difficult 
to generate effective rules, whereas in the biological sense self-assembly is a banal phenomenon. The methods which are prominent within the system of self-arrangement are fractals ${ }^{42}$, agents and the theory of crowd $^{43}$ and cellular automatons ${ }^{44}$.

\section{Cel1ular automaton}

Cellular automaton is a discreet complex dynamic system. It consists of the fields, namely cells arranged in a spatial grid structure. Each cell is in one of the finite number of states, which determine the local rules. The state of a cell depends on its previous state and the previous state of the cells in its immediate, broader or narrower environment - neighborhood. New states of the cells are established in discreet time intervals, and thus it comes to the evolution of the system. The system is self-organized, it reproduces itself. This method is rather interesting for urbanism because through a small set of simple rules complex spatial systems, such as city for instance, are presented. Binary cellular automatons are automatons whose cells possess two possible states - a living one, filled or inhabited cell, and dead, empty or uninhabited cell. Totalistic cellular automatons are 2D automatons whose development does not depend on the arrangement but the number of living cells in the neighborhood. The best known totalistic binary cellular automatons are The Game of Life (1970, mathematician John Horton Conway). The rules of this system are death due to loneliness - each living cell with less than two living neighboring cells dies, death due to overpopulation - each living cell with more than three living neighboring cells dies, keeping alive - each cell with two or three living neighboring cells does not change its state, generation - each cell with exactly three living neighboring cells becomes alive.

\section{Fractal}

Fractal as a system of self-organisation represents a self-organisation example directly taken over from nature. Fractal is a complex, hierarchically ordered structure which establishes self-similarity through different scales. ${ }^{45}$ The notion of self-similarity is understood as the parts reflecting a whole and that being in anyway whatsoever of linear and non-linear self-similarity, self-affinity or statistical self-similarity. Let us take a fractal tree for example. If we notice a big tree branch we will again see the tree in it, and if we focus on the twig from that branch, again we will notice the tree form, etc. Such structures are called fractals. However, such mathematically defined fractal comprises mathematically precisely defined similarity of its parts with a whole and as such it does not appear in nature. In fractals in nature there appears close-similarity or related-similarity of the parts with a whole. In Figure 4 the natural fractal - a 
tree, has been shown. If we start cutting off its branches, their similarity with a whole tree will not be complete, but each branch has the form of a tree.

\section{Agents and crowd theory}

Agents and crowd theory are the types of self-organized systems study of the potential of which in architecture and design is currently in progress. The development of these methods was initiated with the development of technology and is based on the principle of the agents capable of independent actions, capable of learning. The agents in great number "behave" according to the same rules with different input data and there comes to creation of a compact whole. The example in the nature is the crowd theory, namely for example the colony of ants or flock of birds.

The model of an agent as a self-organized model represents the model with an idea of crowd theory. ${ }^{46}$ The crowd theory represents collective movement of a great number of self-propelled (automotive) entities ${ }^{47}$, whereas from the viewpoint of the mathematical model, it is a phenomenal behavior which ensues from simple rules according to which the individuals behave and do not include any central coordination. These models are known under the term of agents or multi-agents.

The model of an agent starts with the rules for behavior and tends to generate, through computer simulations of these rules, the pattern of this behavior. That way the designer, assigning a set of rules according to which each element behaves, comes to certain possible solutions. This principle represents a bottom-up system according to which a design develops, from the local rule towards the general one.

\section{Evolution systems}

There are two types of evolution systems in generative design, and they are evolution systems based on simulation processes of the natural selection and reproduction on computer and evolution systems based on genesis and evolution of design through input of data through layers, It is believed that this type of design has its origin in nature since evolution has primarily been identified in it.

Evolution systems based on simulation processes of natural selection and reproduction on computer ${ }^{48}$ have wider application in various fields, and in architecture as well. The building is ascribed a specification, genetic code, which shows its parameters and technical implementation of the research 
depends on it. Initial population of potential solutions is generated by random selection of parameters values. By intuition or based on the evolution the architect decides about which buildings are appropriate in respect to the criteria laid down. Fitness function may be determined by the designer depending on the design requirements - for instance minimal outdoor area, specified views, layout of rooms in respect to their inter-communications, etc. The solutions selected are further mutually cross-overed in pairs in order to achieve the new population of the units which inherited the properties from their parents. These procedures are repeated until the desired solution has been attained.

The other type of the evolution system represents the system in which input data are entered as per layers and which generate design. By entering increasingly more data the design gradually evolves and becomes increasingly more upgraded and adjusted to its function and the environment (neighborhood). In such system the designer also creates the input data and runs the process until a certain moment when he stops it and declares it a final product.

\section{THE RULES OF CHRISTOPHER ALEXANDER AND THE METHODS OF GENERATIVE DESIGN}

The properties stated by Christopher Alexander as important for the nature of order represent the properties which make integral part of the method of generative design and the building produced by them. The properties and methods of generative design together originate from the nature as being translated into rules and represent the way of practical application in architecture.

Out of fifteen properties of Christopher Alexander, even though it is difficult to draw a line between them, there are those that stand out and which are always present in the methods, those which depend on the selection of algorithms and parameters within it and those which are the consequence of the presence of permanent properties.

The following chapter will elaborate the properties which are always present in the methods, those that form a method, whereas the others are common for all the methods and will not be studied in detail. Such properties are positive space and the void, good shape, simplicity and inner calm.

Positive space and the void represent the properties which predominantly depend on the selection of the algorithm and parameters within it. With a good selection 
of algorithm and parameter these properties are achieved as well. Positive space emerges through mutual organization of the elements of different scales and their spatial harmonization through shaping, whereas the void originates by omitting the elements.

Good shape may be defined as harmony between the elements arranged according to rules, which evokes the feeling of simplicity and inner calm when observing the building. Therefore, good shape, simplicity and inner calm as rules laid down by Alexander, are the consequence of the consistency of application of the remaining rules laid down by him.

Systems of self-arrangement and

rules of Christopher Alexander

\section{Fracta 1}

Since fractal is a self-organized, complex, hierarchically ordered system which establishes self-similarity through various scales, ${ }^{49}$ this method of generative design makes use of the rules of the levels of scale, gradients, and in this order represents the rules of the strong centers, local symmetry, alternating repetitions and echoes. Boundary, contrast and not-separateness are also properties which are characteristic for this method. Positive space and the void are attained by good selection of algorithms and their parameters. Observance of all these rules in a proper way leads to the new ones - good shape, simplicity and inner calm.

In order to achieve order it is understood that the properties have been applied properly according to the explanations of Christopher Alexander. Fractal structure is confirmed by the elements which are repeated in decreasingly smaller scale. By using the rule of the levels of scale, the parts are graded and in a corresponding measure one after another, so that, as stated by Christopher Alexander, when explaining this rule "the jumps from one scale to another would not be overly great. " 50 There originate graded elements organized one in relation to the other. Each part represents a center, so that a whole represents the strongest center, and each scaled element is a sub-center. Since the levels of scale are mutually harmonized the intensities of centers are such that they produce a harmonized whole. Through hierarchy which originates by minimizing the elements there comes to symmetry, Symmetry appears through self-similarity, by repetition and shifting of scaled elements whereby strictness of the usual symmetry is avoided and organic appearance and livingness are achieved. With these rules there comes to alternating repetitions of elements 
and to echoes which comprise the repetition of elements with slight changes in each step. Positive space emerges through inter-organization of the parts in different scales and through their harmonization by shaping, whereas the void originates by omission of the elements and in this case that means the selection of algorithms which do not cause elements overlapping. Since the elements emerge one in relation to the other there also comes to grading. The boundary that emerges between the building and "not-building" allows for the "entry" of the exterior space into the interior one by grading, however, at the same time separates these spaces which produces the boundary which Christopher Alexander speaks about. The boundary gives rise to the contrast between the exterior and the interior. A unique conformed whole is shaped which results in not-separateness. The shapes that originate by this method possess also the property of roughness namely unevenness. By consistency in application of all these rules there originates a good shape which is yet another rule. That also results in simplicity and inner calm.

The example of the building designed by fractal method, a typical Asian temple, is shown in Figure 16. Looking at the temple the levels of scale can clearly be seen through the levels and as far as the tiniest ornaments. That results in desirable arrangement of centers. Centers and spaces which are formed around them are bordered by corresponding boundaries. The graded shape also produces the deep interlock connection with the environment- neighborhood, which additionally connects the building and the environment into a unique whole. The repetition of the elements with minimal differences results in the feeling of inner calm when looking at the temple.

\section{Agents and crowd theory}

The rules of Christopher Alexander contained in the methods of agents and the crowd theory are not-separateness, boundaries, strong centers, levels of scale, gradients, local symmetry, echoes and roughness.

As a self-organized system this method is based on the principle of agents capable of independent actions and capable of learning. The agents in a great number „behave“ according to the same rules with different input data which results in creation of a unique whole, namely not-separateness. Each unit of the whole is a sub-unit by itself which results in separateness, but since great number of units make an inseparable whole, at the same time there comes to not-separateness. Boundaries include the spaces of the units, groups of units and the whole. Contrasts emerge between the spaces occupied by the units, and in certain cases, depending on the algorithm, they emerge between the 
space of the unit and the void. A whole represents a strong center which has been harmonized with units sub-centers and keeps them together. The levels of scaling and gradients exist in the sense of a whole, groups of units and individual units, namely in the sense of behavior according to the individual rules which comes to be due to different input data and form a unique rule of a whole. Due to minimal deviations in behavior of the unit there comes to the local symmetry, and in the same way there comes to creation of echoes. Roughness represents the consequence of echoes and behavior of each unit according to the same rules with different input data - there also often emerge the deviations from the rules which also gives rise to minor differences in behaviors.

The example has been presented in Figure 17. The adaptable flock of Pablo Carranza, the Professor at the CECA University of EastLondon is a form generated on the basis of studying the "flocks" lines which find their places in space on the basis of a sequence of rules.

\section{Cellular automatons}

As a method performing generating on the basis of selection of one of finite many postulated states of cells on the basis of determined rules, and in relation to the other, neighboring cells, namely centers this system of self-arrangement uses the following rules of Christopher Alexander - alternating repetitions, local symmetry, strong centers, positive space, boundaries, roughness, and in some cases the levels of scale, gradients and echoes. Through a defined set of rule, with a specified number of possible solutions there comes to alternating repetitions of the structures with the same neighborhoods, whereby local symmetry of the shifted groups of elements in space is achieved. Since this method is based on neighborhood, namely generates new components based on the neighboring ones, it is a very important property of boundaries. Boundary occupies the space of cells and indicates neighborhoods - it is formed around the centers of the (cells), as well as the sets of centers of the (cells), namely neighborhoods. Since neighborhoods, and the cells also, most often possess different properties there emerges the contrast between the groups which accentuates the boundaries. The rule of roughness emerges since the boundaries are most frequently uneven. Not-separateness is achieved though group of cells, centers which function depending one on the others. With a replacement of one cell the replacements of neighboring cells are initiated, and thereby of a whole as well. Positive space is achieved by applying the method. The elements are not mutually threatened since they find themselves individually within the clear boundaries of cells. The void emerges with the 


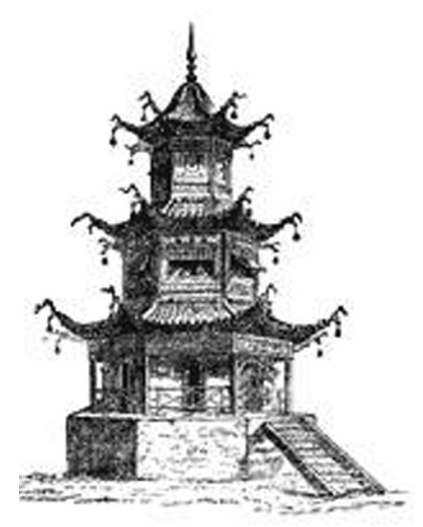

Figure 16: Fractal method in typical Asian temple
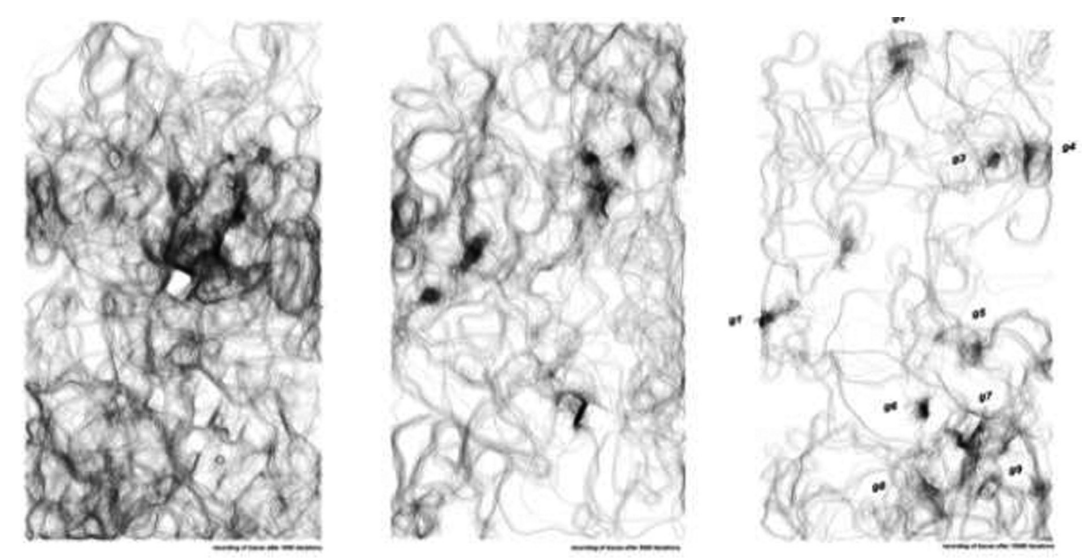

Figure 17: Adaptable flock of Pablo Caranse, Agents and the crowd theory

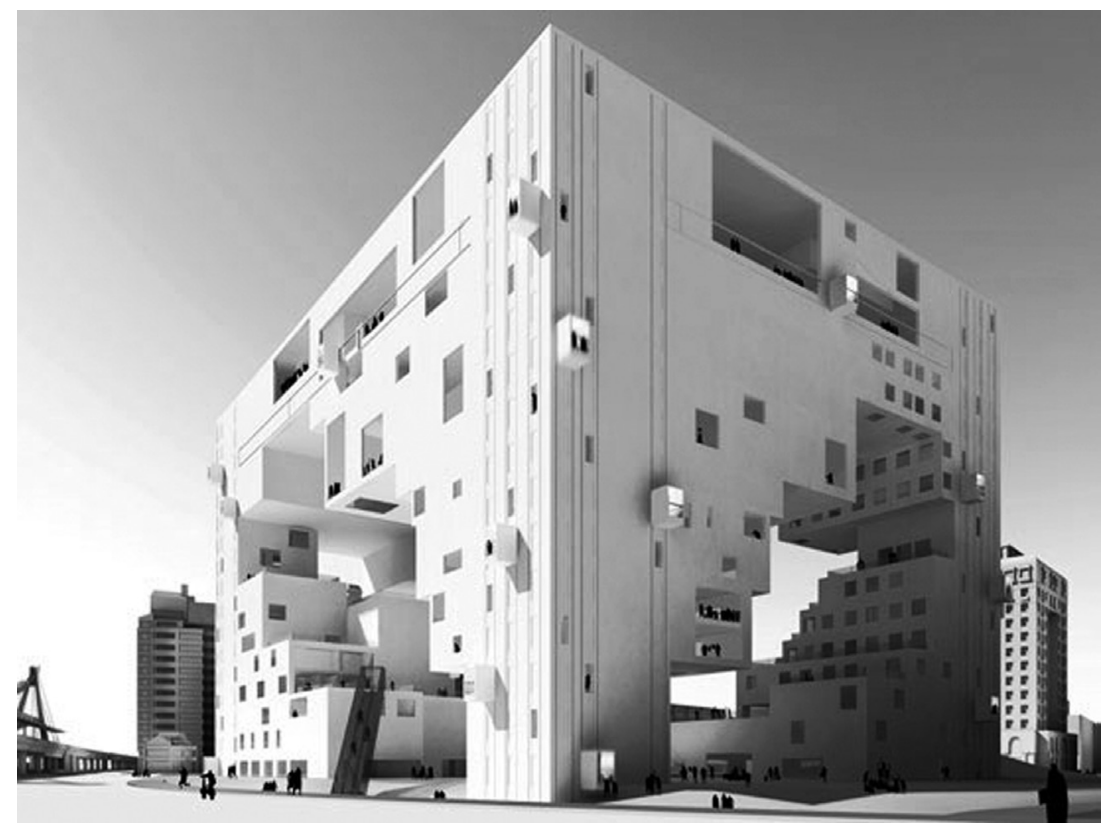

Figure 18: Method of cellular automatons, Cultural center in Taipei, NK Architects

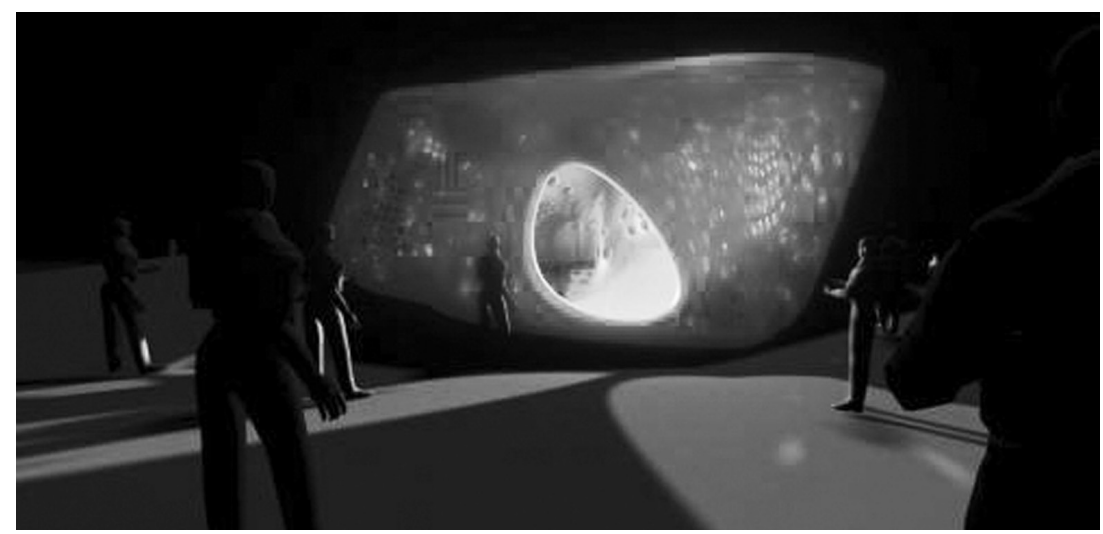

Figure 19: Method of evolution systems Pavilion a UIC Masters Biodigital Architecture 
algorithm and parameters through omissions of elements or cells, namely part of the grid. Within this method the levels of scaling and gradients are achieved through algorithm. Such cellular automatons possess properties of a fractal as the neighborhoods are repeated in different scales, and thus the buildings generated this way demonstrate the properties of echoes.

This method has found its use in urbanism ${ }^{51}$ and has been successfully used in urbanism centers worldwide, whereas within frames of architecture it is in experimental stage. The example in Figure 18 is an unbuilt competition building of the Cultural Center in Taipei by the NL Architects team of architects. This design was developed as a cellular automaton whose each cell represents subunits of apartments. The void which emerges was formed on the basis of the level of insolation, the view and sound breaking up.

\section{Evolution systems and the rules of Christopher Alexander}

The method of evolution system based on simulation processes of natural selection and reproduction makes use of several rules of Christopher Alexander - strong centers, boundaries, alternating repetitions, local symmetry and echoes. The evolution system based on simulation processes of natural selection and reproduction which by cross-overing of units declared as parents generate new units, connect strong centers of units whereby new unit originates with a new center which possesses sub-wholes of the parents as their sub-centers. Thus the boundaries of these two initial units are transformed into a new boundary. Alternating repetitions of the various properties through generations results also in echoes which little by little change certain properties of the unit through generations. Such transmission of properties, by combining the properties of the parents, results in newly generated unit which is symmetrical, self-similar in its part to the parents.

The units generated by crossbreeding possess the properties contained in the method and it possesses the properties determined by initial population. It is necessary to develop population in order not to lose the desired properties.

The example has been presented in Figure 19 in Chapter 6.0 Graphic presentations. The Pavilion designed within UIC Masters Degree in Biodigital Architecture program is the result of crossbreeding of various shapes generated on the basis of different ergonomic positions of people. The final product combines a great number of the different ergonomically adjusted sections. 


\section{CONCLUSION}

The phenomenon of life which Christopher Alexander writes about makes it possible to observe the environment in a different way. Christopher identifies liveliness in everything. That which he calls life is the order which is generated from the arrangement according to the rules postulated by him in his book "The Nature of Order - The Phenomenon of Life". The rules are noticed by Alexander in nature and are translated into architecture with a goal of creating a more agreeable living environment for the man than the present one.

Through practical application of Alexander's theory of the „nature of order“ in architecture there comes to merging of fifteen rules and methods of generative design, whereby the principles from the nature are translated into methods the system of self-arrangement and evolution systems, namely artefacts which originate by this methods.

Generative systems behave same as the natural ones as through the methods of generative design the rules are incorporated in them, namely the properties laid down by Alexander, whereby the order is introduced in such buildings. Since such buildings are the derivatives of algorithm methods they behave as the natural ones in the sense of the possibility of adaptation, reproduction and complexity of processing of information that shape it. That way such buildings ambiguously incorporate the properties assumed from nature.

Not all the rules are equally represented in the methods. The method that stands out as having applied the properties the most are fractals as self-organized system. This is the consequence of direct adoption of the method from nature in an obvious physical way, thus this was the reason it was adopted already back in the ancient civilizations. Agents and the crowd theory and cellular automatons result from the principles of nature functioning, and thus do not apply the rules in the same measure as the fractal method. Evolution method represents the evolution algorithm, It is not possible to identify all properties individually within this method, but, yet, they appear in the structures created as this method combines other methods as well.

Some rules, such as positive space, the void, ambiguity, are not always present in the methods and it is necessary to incorporate them in the algorithm in order for the building to possess these properties. The rule of good shape, simplicity and inner calm are the result of the use of the remaining rules in an appropriate way. 
It is necessary to further develop these methods in order for their results to develop the level of order such as appears in nature. One of the possible directions of their development could be the rules of Christopher Alexander. Also, they need to be studied through all these properties. Mathematical concept of calculation of livingness, the presence of the fifteen properties, exactly makes that possible. The concept offered by Salingaros is the initial solution and does not study each of the fifteen properties of Christopher Alexander but indicates to the possibility of development of such model.

Ibid.

Ibid.,p. 9 
(Berkeley, California: The Center of Environmental Structure, 2002), 55. Generally accepted definition of life: Life is represented by a cycle through which any organism made of carbon, oxygen, hydrogen and nitrogen goes through, and which is capable of reproduction, healing and to remain stable for certain period of time.

Alexander, THE NATURE OF ORDER Book 1, 32-33

Ibid., 96.

Ibid., 84.

Ibid.

Ibid., 117.

Ibid., 112.

Ibid., 126-127.

Ibid., 140.

Ibid., 146-147.

Ibid., 151-153.

Ibid., 158-159.

Ibid., 165.

Ibid., 173.

Ibid., 179.

Ibid., 183.

Kim Williams, "A Architecture and Mathematics: Simmetry in architecture,"NEXUS Network Yournal 11/3 (2009): 339-331.

Basic symmetry is called bilateral symmetry and represents copying in respect to the axis. Besides this symmetry there are also many other types of symmetry which give rise to creation of self-similar buildings. These are the symmetry created by rotation and reflection, cylindrical symmetry, chiral symmetry, self-similar symmetry, spiral symmetry and helicoid symmetry, translator symmetry. These symmetries may be combined which results in symmetrical but also mutually rather different shapes.

Alexander, THE NATURE OF ORDER Book 1, 200.

Ibid., 205.

Ibid., 218.

Ibid., 210.

Ibid., 222.

Ibid., 216.

Ibid., 230.

Ibid., 469-472.

Ibid.

Thomas Kuhn, The Structure of Scientific Revolutions (Chicago: University of Chicago Press, 1996), 135-139.

Jon McCormack, Alan Dorin and Troy Innocent, "Generative design: a paradigm for design research," in Redmond - Proceedings of Futureground (Design Research Society, 2004), 1-2. Nikos Salingaros and Kenneth Masden, "Architecture: Biological Form and Artificial Intelligence," The Structurist No 45/46 (2006): 57.

Jon McCormack, Alan Dorin and Troy Innocent, "Generative design: a paradigm for design research,4-5.

Benoît Mandelbrot, The fractal geometry of nature (New York: Freeman, 1982).

Fractal is a complex, hierarchically organized structure which establishes self-similarity through various scales. The notion of self-similarity is understood as that the parts illustrate the whole and that being in any way of linear and non-linear self-similarity, self-affinity or static self-similarity. However, such mathematically defined fractal comprises mathematically precisely defied similarity of its parts with a whole and as such it does not appear in nature. In fractals in nature there appear close-similarity or related-similarity of parts with a whole. 
York: Routledge, 1997).

Agents and crowd theory are the types of self-organized systems the potential of which in architecture and design is currently studied. The development of these methods was initiated with the development of technology and is based on the principle of the agents capable of independent actions, capable of learning. The agents in great number "behave" according to the same rules with different input data and there comes to creation of a compact whole. The example in the nature is the crowd theory, namely for example the colony of ants or flock of birds.

The model of an agent as a self-organized model represents the model with an idea of crowd theory. The crowd theory represents collective movement of a great number of self-propelled (automotive) entities, whereas form the viewpoint of the mathematical model, it is a phenomenal behavior which ensues form simple rules according to which the individuals behave and do not include any central coordination. These models are known under the term of agents or multiagents.

The model of an agent starts with the rules for behavior and tends to generate, though computer simulations of these rules, the pattern of this behavior. That way the designer, assigning a set of rules according to which each element behaves, comes certain possible solutions. This principle represents a bottom-up system according to which a design develops, from the local rule towards the general one.

Stephen Wolfram, A new kind of science (Champaign: Wolfram Media, 2002).

Cellular automaton is a discreet complex dynamic system. It consists of the fields, namely cells arranged in a spatial grid structure. Each cell is in one of the finite number of states, which determine the local rules. The state of a cell depends on its previous state and the previous state of the cells in its immediate, broader or narrower environment - neighborhood. New states of the cells are established in discreet time intervals, and thus it comes to the evolution of the system. The system is self-organized, it reproduces itself. This method is rather interesting for urbanism because through a small set of simple rules complex spatial systems, such as city for instance, are presented.

Binary cellular automatons are automatons whose cells possess two possible states - a living one, filled or inhabited cell, and dead, empty or uninhabited cell. Totalistic cellular automatons are 2D automatons whose development does not depend on the arrangement but the number of living cells in the environment/neighborhood. The best known totalistic binary cellular automatons are The Game of Life (1970, mathematician John Horton Conway). The rules of this system are - death due to loneliness -each living cell with less than two living neighboring cells dies, death due to overpopulation - each living cell with more than three living neighboring cells dies, keeping alive - each cell with two or three living neighboring cells does not change its state, generation - each cell with exactly three living neighboring cells becomes alive.

Ibid.

Jon McCormack, Alan Dorin and Troy Innocent, "Generative design: a paradigm for design research", in Redmond - Proceedings of Futureground (Design Research Society, 2004), 5-6. Benoît Mandelbrot, The fractal geometry of nature (New York: Freeman, 1982), 12-32.

Alexander, THE NATURE OF ORDER Book 1, 146-147.

MOLAND Monitoring Land Use (European Commission, Joint Research Centre, Institute for Environment and Sustainability) is one of the European Research centers which for a quite many years has been using the method of cellular automatons. 
Alexander, Christopher. Book 1: The Phenomenon of Life. Berkeley. California: The Center of Environmental Structure, 2000.

Alexander, Christopher. Book 2: The Process of Creating Life. Berkeley. California: The Center of Environmental Structure, 2002.

Alexander, Christopher. Book 3: A Vision of a Living World. Berkeley, California: The Center of Environmental Structure, 2003.

Alexander, Christopher. Book 4: The Luminous Ground. Berkeley. California: The Center of Environmental Structure, 2004.

Fischer, Thomas and Christiane Herr. Teaching Generative Design. Hong-Kong: Design Technology Research Center, School of Design. 2003.

Leach, Neil and Roland Snooks. Swarm Intelligence: Architectures of Multi-Agent Systems. New York: Routledge, 1997.

Mandelbrot, Benoît. The fractal geometry of nature. New York: Freeman, 1982.

Williams, Kim. "Architecture and Mathematics: Simmetry in architecture." NEXUS Network Yournal 11/3 (2009).

Wolfram, Stephen. A new kind of science. Champaign: Wolfram Media, 2002.

Chien, Sheng-Fen and Urlich Flenning. INFORMATION NAVIGATION IN GENERATIVE DESIGN SYSTEMS. Department of Architecture, Carnegie Mellon University,2002.

Fischer, Thomas and Christiane Herr. Teaching Generative Design. Hong-Kong: Design Technology Research Center, School of Design. 2003.

Hanington, Bruce. GENERATIVE RESEARCH IN DESIGN EDUCATION. Carnegie Mellon University School of Design, 2007.

Kuhn, Thomas. The Structure of Scientific Revolutions. Chicago: University of Chicago Press, 1996.

Lawson, Bryan. How Designers Think. Description of the design Process. The Components of Design Problems. Eastview Editions, 1980.

McCormack, Jon, Alan Dorin and Troy Innocent. "Generative design: a paradigm for design research." in Redmond - Proceedings of Futureground. Design Research Society, 2004.

Mehaffy, Michael. "Generative Methods in Urban Design: a Progress Assessment." Journal of Urbanism: International Research on Placemaking and Urban Sustainability Vol.1, No.1 (March 2008): 57-75.

Salingaros, Nikos and Kenneth Masden. "Architecture: Biological Form and Artificial Intelligence,” The Structurist No 45/46 (2006): 54-61.

Geiser, Reto. Exploration in Achitecture, Teaching Design Research. Switzerland: Birkhauser. pp 122-123

Geiser, Reto. Exploration in Achitecture, Teaching Design Research. Gerber, Andri. Notes on the Analysis of Form: Christopher Alexander and the Language Patterns. Switzerland: Birkhauser. pp 34-47 and 80-89 and 122-123

Geiser, Reto. Exploration in Achitecture, Teaching Design Research. Kwinter, Stanford. A discourse of Method. Switzerland: Birkhauser, pp 34-47

Geiser, Reto. Exploration in Achitecture, Teaching Design Research. Latour, Bruno and Yaneva, Albena. An Ant's View of Architecture. Switzerland: Birkhauser, pp 80-89

Switzerland

Maldonado, Tomas. Design Research. Politecnico di Milano. Hanington, Bruce. Innovation and Method in Design Research. Carnagie Mellon University, USA (18-20 May 2000) 
IMAGE CREDITS

Figure 1. Left: Alexander, Christopher. Low degree of the levels of scale in the Nature of Order, Book 1: The Phenomenon of Life, p. 147. Center: Alexander, Christopher. High degree of the level of scales in the Nature of Order, Book 1: The Phenomenon of Life, p. 147. Right:Alexander, Christopher, Example of the levels of scale in nature, crevices in dried land in the Nature of Order, Book 1: The Phenomenon of Life, p. 250

Figure 2. Left: Alexander, Christopher. The floor plan of an unknown building, minor harmonization of the centers in the Nature of Order, Book 1: The Phenomenon of Life, p. 155. Center: Lloyd Wright, Frank, The floor plan of the first level of the Robie residence, Greater harmonization of centers, Great Buildings, JPG, http://www.greatbuildings.com/architects/Frank_Lloyd_Wright. html (downloaded on 11.11.2011). Right: Alexander, Christopher. Example of strong centers in nature, a drop of milk in the Nature of Order, Book 1: The Phenomenon of Life, p. 251

Figure 3. Left: Alexander, Christopher. Traditional Norwegian storage house, multitude of boundaries in the Nature of Order, Book 1: The Phenomenon of Life, p. 158. Center: Alexander, Christopher. Building dating from middle of the twentieth century, absence of boundaries in the Nature of Order, Book 1: The Phenomenon of Life, p. 159. Right: Alexander, Christopher. Example of clear boundary in the Nature of Order, Book 1: The Phenomenon of Life, p. 254

Figure 4. Left: Alexander, Christopher. Turkish velvet, alternating repetitions create livingness in the space in the Book 1: The Phenomenon of Life, p. 165. Right - Alexander, Christopher. ПExample of alternating repetitions in nature, undulation of water in the, Book 1: The Phenomenon of Life, p. 258

Figure 5. Left: Nolli, Giambattista. Positive space in Rome plan by Giambattista Nolli, JPG,http://udu. ff.cuni.cz/soubory/galerie/baroko\%20italie/slides/001\%20Giovanni\%20Battista\%20Nolli, $\% 20$ plan\%20Rima,1748.html (downloaded on 21.11.2011). Right: Alexander, Christopher. Example of positive space in nature, leaves in the Book 1: The Phenomenon of Life, p. 263

Figure 6. Left: Alexander, Christopher. Foot stool,good shape in the Book 1: The Phenomenon of Life, p. 181. Right: Alexander, Christopher. Example of good shape in nature, drop of water in the Book 1: The Phenomenon of Life, p. 265

Figure 7. Left: Alexander, Christopher. Renaissance Center, brutal symmetry without adaptation of the whole to the parts and vice versa in the Book 1: The Phenomenon of Life, p. 187. Center: Alexander, Christopher. Alhambra, Moorish fortress in Grenada, good symmetrical order p. 187. Right: Drawing of the author of the text (2011). Example of local symmetry in nature, fern.

Figure 8. Left: Alexander, Christopher. Wooden foot-bridge joint in the Book 1: The Phenomenon of Life, p. 195. Center: Alexander, Christopher. Capital and beam joint in the Book 1: The Phenomenon of Life, p. 195. Right: Alexander, Christopher. Example of deep interlock in nature, pattern of giraffe's fur in the Book 1: The Phenomenon of Life, p. 271

Figure 9. Left: Alexander, Christopher. Contrast on the façade of the Tuscany church in the Book 1: The Phenomenon of Life, p. 204. Right - Alexander, Christopher. Example of contrast in nature, beryllium and iron in the Book 1: The Phenomenon of Life, p. 273

Figure 10. Left: Alexander, Christopher. Gradients,cornice in the Book 1: The Phenomenon of Life, p. 205. Right: Alexander, Christopher. Example of gradients in nature, gradients formed by the snail shell growth in the Book 1: The Phenomenon of Life, p. 277.

Figure 11. Left: Alexander, Christopher. Building in South Italy, echoes in the Book 1: The Phenomenon of Life, p. 209. Right: Alexander, Christopher. Example of echoes in nature, wrinkles in the Book 1: The Phenomenon of Life, p. 281

Figure 12. Figure 12: Left: Alexander, Christopher. Columns which clearly, roughly accentuate the space in the Book 1: The Phenomenon of Life, p. 214. Center: Alexander, Christopher. A wall carefully filled with stone in the Book 1: The Phenomenon of Life, p. 217. Right: Alexander, Christopher. Example of roughness in nature, shell in the Book 1: The Phenomenon of Life, p. 279

Figure 13. Left: Alexander, Christopher. Non-expressed void in typical business building in the Book 1: The Phenomenon of Life, p. 223. Center: Alexander, Christopher. Expressed mosque in Cairo in the Book 1: The Phenomenon of Life, p. 223. Right: Alexander, Christopher. Example of the void in 
nature, gorge in the Book 1: The Phenomenon of Life,p. 285

Figure 14. Left: Alexander, Christopher. Cabinet, expressed calm in the Book 1: The Phenomenon of Life, p. 226. Center: Alexander, Christopher. Italian chairs, absence of calm in the Book 1: The Phenomenon of Life, p. 226. Right: Alexander, Christopher. Example of simplicity and inner calm in nature, leaf of gingko in the Book 1: The Phenomenon of Life, p. 287

Figure 15. Left: Alexander, Christopher. Inter-connected path in the Book 1: The Phenomenon of Life, p. 233. Right: Alexander, Christopher. Example of not-separateness in nature, boundary of the lake in the Book 1: The Phenomenon of Life, p. 289

Figure 16. Sketch of an unknown author. Method of fractal on the typical Asian temple. UNESCO, JPG, http://whc.unesco.org/en/list/668 (downloaded on 12.10.2011)

Figure 17. Miranda Carranza, Pablo. Adaptable flock, agents and the crowd theory. Swarm modelling. http://www.generativeart.com/on/cic/2000/CARRANZA_COATES.HTM (downloaded on 12.10.2011)

Figure 18. NL Architects. Method of cellular automatons, Cultural center in Taipei, NL Architects, JPG, http://www.nlarchitects.nl/project/9/slideshow (downloaded on 12.10.2011)

Figure 19. Chu, Karl. Method of evolution systems, UIC Masters Degree in Biodigital Architecture http:// www.mayaprzybylski.com/systemstalkerlab/?p=2033 (downloaded on 12.10.2011) 
PETNAEST PRAVILA KRISTOFERA ALEKSANDERA I METODE GENERATIVNOG PROJEKTOVANJA KAO PRAKTIČNA PRIMENA „PRIRODE REDA“ U ARHITEKTURI

\section{Ivana Petruševski}

Rad uspostavlja korelaciju između „prirode reda“ Kristofera Aleksandera i metoda generativnog projektovanja, kao i njihovu vezu sa prirodom. Istraživanje se usredsređuje na praktičnu primenu teorije Kristofera Aleksandera o preuzimanju principa iz prirode, sa ciljem pomirenja izgrađenog okruženja sa prirodnim i stvaranja pogodnije životne sredine od sadašnje, pomoću generativnog, parametarskog projektovanja u arhitekturi i urbanizmu. Kristofer Aleksander red vidi u prirodi, dok ljudska vrsta stvara potpuno novu vrstu „reda“ gradeći objekte i gradove, iako nije potpuno svesna značenja ovog pojma. Kako bi se uspostavila ravnoteža između ova dva reda, odnosno jedinstvo između ova dva kompleksna sistema - prirodnog i arteficijalnog, potrebno je prema rečima Kristofera Aleksandra preneti principe iz sistema koji dobro funkcioniše, prirode, u arteficijalni sistem. Ovaj rad istražuje vezu ,prirode reda“, odnosno ,petnaest pravila“ Kristofera Aleksandera sa metodama generativnog projektovanja, paralelno tragajući za korelacijama u prirodi. Pravila se povezuju sa metodama samoslaganja i evolutivnim metodama kao primarnim metodama generativnog projektovanja.

KLJUČNE REČI: PRAVILA KRISTOFERA ALEKSANDERA, METODE GENERATIVNOG PROJEKTOVANJA, PRIRODA REDA, FENOMEN ŽIVOTA, SISTEMI SAMOSLAGANJA I EVOLUCIONI SISTEMI

TEKSTILNA ARHITEKTURA: ISTRAŽIVANJE POTENCIJALA SKLOPOVA VLAKANA I NJIHOVU PRIMENU U ARHITEKTURI

\section{Milutin Cerović}

Rad istražuje odnos između tekstilnih materijala i arhitekture, kako se ovaj odnos razvija kroz saradnju tekstilnih inženjera i arhitekata. Određene karakteristike tekstila oduvek su bile zanimljive arhitektama. Veliki broj vlakna organizovan u fleksibilne strukture koje mogu da propuštaju svetlost i vazduh ili da se prilagođavaju ljudskom telu i njegovim aktivnostima, kroz istoriju su arhitektama služile kao metafora. Danas kombinovanje tekstila sa softverom, robotikom i senzorima nudi razmišljanje o arhitektonskoj formi koja se prilagođava i reaguje u zavisnosti od događaja koji se odvija u prostoru. Istraživanje zalazi u samu strukturu materijala i ispituje tendencije $u$ materijalizaciji vlaknastih struktura. Cilj je da se tekstili predstave kao novi materijal čija primena i implementacija u arhitekturi može da utiče na razvoj novih ideja, kreiranje estetskog i kulturnog konteksta. 